\title{
Application of DNA Shuffling as a Tool for Hydrolase Activity Improvement of Pseudomonas Strain
}

\author{
Morteza Mirzaei ${ }^{1}$ (D), Mona Rastegar Shariat Panahi ${ }^{2}$, Enayat Ghahremani ${ }^{1}$, Ehsan Rezae ${ }^{3}$, Rezvan Seid \\ Moradi ${ }^{1}$, Elahe Tahmasebi ${ }^{4}$ (D) , Gholamreza Farnoosh', Ali Mohammad Latifi 1,*(D) \\ 1 Applied Biotechnology Research Center, Baqiyatallah University of Medical Sciences, Tehran, Iran \\ 2 Department of Biochemistry, Payame Noor University, Tehran, Iran \\ 3 Molecular Biology Research Center, Systems biology and poisonings Institute, Baqiyatallah University of Medical \\ Sciences, Tehran, Iran \\ 4 Research Center for Prevention of Oral and Dental Diseases, Baqiyatallah University of Medical Sciences, Tehran, Iran \\ * Correspondence: amlatifi290@gmail.com;
}

Scopus Author ID 54880840300

Received: 2.06.2020; Revised: 30.06.2020; Accepted: 30.06.2020; Published: 3.07.2020

\begin{abstract}
Biotechnology is considered one of the most influential technologies in various areas of human life, including health, economics, and the environment. Protein engineering is one of the major biotechnology tools in the field of modification and advancement of biocatalysts capabilities. Among the most effective protein engineering methods, in particular, to improve the industrial strain capabilities, is the shuffling genome method. This study aimed to follow knowledge and biocatalysts engineering techniques based on DNA shuffling methods. In the first step, two procedures were followed (DES method and compatibility according to the concentration gradient of Diazinon) to obtain mutant strains. Acquired mutant strains from both methods were resistant to high concentrations of poison up to $3000 \mathrm{mg} / \mathrm{L}$. The activity of these strains also demonstrated their elevated activity compared to parent samples. The highest activity was related to four strains IR1.G1, IR1.D8, IR1.D4, and IR1.D5, which were $0.234 \mathrm{U} / \mathrm{ml}, 0.1 \mathrm{U} / \mathrm{ml}, 0.098 \mathrm{U} / \mathrm{ml}$, and $0.066 \mathrm{U} / \mathrm{ml}$, respectively. The improved strain was obtained via the concentration gradient of the diazinon method (IRL1.G1 strain) in comparison with IRL1.D8 strain (owning highest activity through DES method) possesses excessive activity in 3000 $\mathrm{mg} / \mathrm{L}$ concentration of Diazinon. The evaluated results of first-generation genome shuffling of strains (the first round of protoplast fusion) also indicated that those shuffled strains with the ability to grow in the vicinity of the toxin $(3000 \mathrm{mg} / \mathrm{L}$ concentration of Diazinon) showed better activity than obtained mutated strains by both methods (concentration gradient of the toxin and the DES method). In the final stage, the best results were related to IRL1.F2, IRL1.F3, and IRL1.F1 shuffled strains with $0.541 \mathrm{mg} / \mathrm{L}$, $0.523 \mathrm{mg} / \mathrm{L}$, and $0.509 \mathrm{mg} / \mathrm{L}$, respectively. The highest activity belonged to the IRL1.F2 genome shuffled strain (first round of protoplast fusion). This strain could grow in a high concentration of toxin, and also, the activity was increased 30, 3.6, and 2.3 times in comparison with the parent strain (IRL1), IRL.D8 mutant, and IRL1.G1, respectively.
\end{abstract}

Keywords: Diazinon; genome shuffling; improved strain; protein engineering.

(C) 2020 by the authors. This article is an open-access article distributed under the terms and conditions of the Creative Commons Attribution (CC BY) license (https://creativecommons.org/licenses/by/4.0/).

\section{Introduction}

Organophosphorus (Op) insecticides have been used for agricultural purposes globally in recent decades. Numbers of OP compounds can be named, such as Malathion, Dichlorvos, Parathion, and Chlorpyrifos. OPs target Acetylcholinesterase (AChE), which is a vital enzyme in hydrolyzing neurotransmitter acetylcholine, leading to inactivation of AChE and thus 
causing toxicity [1-4]. Accordingly, the usage of these compounds generates health concerns toward humans and other living creatures. To conquer this problem, many efforts have been made, and different approaches have been used to eliminate the contamination arising from the use of these compounds. Methods such as physical, chemical, and biological can be mentioned as decontamination strategies [5-9]. Biodegradation is regarded as an outstanding method due to some prominent characteristics like quick action, environment-friendly, safe and reduced toxicity of products [10-14].

Previous studies have proved that some microorganisms can decontaminate specific toxic compounds [15]. Several isolated bacteria, namely Flavobacterium sp. and Pseudomonas diminuta $M G$ have shown to own significant capabilities to hydrolyze Ops [16, 17]. Pseudomonas sp. is considered an outstanding candidate for Ops biodegradation and is used for the decontamination of contaminated effluents and agricultural soils [18, 19].

Despite numerous benefits of using bacterial strains in the biodegradation process, some application aspects of these strains deter their frequent use. One of the limiting factors is substrate availability. The cytoplasmic enzymes of these bacteria are responsible for their bioactivity, which limits access to the substrate. On the other hand, they require a longer time to act on the substrate, thus decreasing their quality of efficiency $[20,21]$.

In case of having access to the details of enzyme properties, researchers have attempted to improve the hydrolase activity of several enzymes through several methods [22]. Genome shuffling is widely used for increasing the production of metabolites by bacterial strains, improving substrate uptake as well as enhancing strain tolerance. This technique combines the advantage of multiparental crossing allowed by DNA shuffling together with the recombination of entire genomes normally associated with conventional breeding, or through protoplast fusion, that increases the recombination process. Stemmer and co-workers first presented the method of genome shuffling in 2002 when it was used to improve the production of tylosin by Streptomyces fradiae. Nowadays, it is used in many experiments for increasing the production of metabolites by bacterial strains, improving substrate uptake, and enhancing strain tolerance. Genome shuffling is a major milestone in strain-improvement technology and metabolic engineering [23, 24]. In this study, we made an effort to improve the properties of Pseudomonas aeruginosa to degrade Diazinon, using the genome-shuffling technique. Toxicity resistance to Ops and an increase in whole-cell activity is aimed in this study. The main goal is to obtain a mutant strain, which can grow in high concentrations of Diazinon and, on the other hand, degrade Diazinon efficiently in a short time.

\section{Materials and Methods}

\subsection{Bacterial strain.}

Wild type Pseudomonas aeruginosa JQ917006.1 (IRLM.1) was isolated from industrial wastewaters (effluents of pesticide producing factories and their contaminated soil) in Iran (Genbank accession number: JQ917006.1).

\subsection{Chemicals and reagents.}

Diazinon (99.5\% purity) was purchased from Sigma-Aldrich. The other chemicals and solvents were obtained from Merck, Germany. 


\subsection{Native strain tolerance test against Diazinon.}

In the beginning, the isolated $P$. aeruginosa strain IRLM.1 was cultured in mineral salt medium (MSM) broth $\left(0.1 \mathrm{~g} / \mathrm{L} \mathrm{NaCl}, 0.2 \mathrm{~g} / \mathrm{L} \mathrm{KCl}, 0.5 \mathrm{~g} / \mathrm{L}\left(\mathrm{NH}_{4}\right)_{2} \mathrm{SO}_{4}, 50 \mathrm{mg} / \mathrm{L} \mathrm{CaCl}_{2} . \mathrm{H}_{2} \mathrm{O}\right.$, $2 \%(w / v)$ glucose) without Diazinon and was incubated at $37^{\circ} \mathrm{C}$ until $\mathrm{OD}_{600}$ reached to 0.5 (measured by NanoDrop spectrophotometer, Thermo Scientific, DE, USA). The bacterial suspension was centrifuged (at $7000 \mathrm{rpm}$ for $5 \mathrm{~min}$ ) and then was washed with MSM broth without glucose for several times. In the next step, bacterial crude was added to MSM agar (0.1 $\mathrm{g} / \mathrm{L} \mathrm{NaCl}, 0.2 \mathrm{~g} / \mathrm{L} \mathrm{KCl}, 0.5 \mathrm{~g} / \mathrm{L}\left(\mathrm{NH}_{4}\right)_{2} \mathrm{SO}_{4}, 50 \mathrm{mg} / \mathrm{L} \mathrm{CaCl}_{2} \cdot \mathrm{H}_{2} \mathrm{O}, 15 \mathrm{~g} / \mathrm{L}$ agar) and broth without glucose, supplemented with 1000 to $3000 \mathrm{mg} / \mathrm{L}$ diazinon and then incubated for $72 \mathrm{~h}$ at $37^{\circ} \mathrm{C}$. Genome shuffling was carried out through two routes: 1. Chemical adaptation (IRLM1.G strain) 2. DES mutation inducing material (IRLM1.D strain).

\subsection{Creation of mutant library (IRLM1.G) via chemical adaptation.}

The first population obtained by chemical adaptation, which included a gradual increase in diazinon amount within $1200 \mathrm{~h}$. This could be explained in this way that after confirming the resistance of native bacteria, they were exposed to higher concentrations of Diazinon (2500$3000 \mathrm{mg} / \mathrm{l}$ ) on MSM agar. Afterward, the cultures were incubated for $72 \mathrm{~h}$ at $37^{\circ} \mathrm{C}$ and were kept in a dark place to avoid photo-degradation of Diazinon.

\subsection{Creation of mutant strains (IRLM1.D) by diethyl sulfate (DES).}

The native strain was cultured in the MSM medium and was incubated at $37^{\circ} \mathrm{C}$ until the $\mathrm{OD}_{600}$ reached 0.5 . The media was treated with $0.5 \%, 1 \%, 1.5 \%, 2 \%, 2.5 \%$, and finally, $3 \%$ of DES (Sigma Aldrich) and then was incubated for $72 \mathrm{~h}$ at $37^{\circ} \mathrm{C}$. The bacterial suspension was centrifuged (at $7000 \mathrm{rpm}$ for $5 \mathrm{~min}$ ) and then was washed with PBS. Eventually, the obtained pellet was cultured in LB agar.

2.6. Screening based on growth in the presence of monocrotophos and biodegradation of Diazinon in the liquid medium.

The obtained mutant library was cultured on LB agar and incubated at $37^{\circ} \mathrm{C}$ for $48 \mathrm{~h}$. Then a thin layer of agarose $0.7 \%$ containing $50 \mathrm{mM}$ phosphate-citrate buffer and $0.5 \mathrm{mM}$ monocrotophos was added to media and incubated for $1 \mathrm{~h}$ at $37^{\circ} \mathrm{C}$. The colonies were selected based on the magnitude of the halo. The selected colonies were inoculated to MSM broth containing Diazinon $(2000,2500$, and $3000 \mathrm{mg} / \mathrm{L})$ as the sole carbon source. $\mathrm{OD}_{246}$ was measured at 0, 24, 48, and $72 \mathrm{~h}$ using NanoDrop (Thermo Scientific, DE, USA). As mentioned earlier, all the experiments related to Diazinon were done in dark condition due to the effects of light on Diazinon [25-29].

\subsection{Protoplast preparation and inactivation treatment.}

Protoplasts were prepared [30] except for a few modifications. The bacterial cells were cultured on MSM broth overnight at $37^{\circ} \mathrm{C}$, and then cells were harvested by centrifugation at $7000 \mathrm{rpm}$ for $5 \mathrm{~min}$. The bacterial cells were suspended in $10 \mathrm{ml}$ protoplast buffer (PB), containing $10 \mathrm{mM}$ Tris- $\mathrm{HCl}, 20 \mathrm{mM} \mathrm{CaCl}_{2}$, and $0.5 \mathrm{M}$ sucrose along with $1 \mathrm{mg} / \mathrm{ml}$ lysozyme and incubated at $60^{\circ} \mathrm{C}$ for $2 \mathrm{~h}$ for inactivation. Protoplast formation was observed microscopically by a light microscope. 


\subsection{Genome shuffling.}

The starting populations for genome shuffling were mutants-library-generated by the gradually high concentration of diazinon adaptation and DES factor. Inactivate protoplasts were mixed in a ratio of $1: 1$ and collected by centrifugation followed by resuspension in the ratio of 9:1 of PEG $6000(60 \%)$ and PB, respectively, and incubated for $30 \mathrm{~min}$ at $37^{\circ} \mathrm{C}$. The fused protoplasts were suspended in $5 \mathrm{ml} \mathrm{PB}$ and were centrifuged at $3000 \mathrm{rpm}$ for $20 \mathrm{~min}$ at $25^{\circ} \mathrm{C}$. The pellets were regenerated on regeneration medium $(20 \mathrm{mM}$ magnesium chloride, 0.5 $\mathrm{M}$ sucrose, and $10.5 \% \mathrm{BSA}$ ) for $18 \mathrm{~h}$ at $37^{\circ} \mathrm{C}$.

\subsection{Analytical method.}

The screening was performed based on growth in the presence of monocrotophos and fusants were selected. Moreover, diazinon biodegradation and resistance against Diazinon were evaluated according to which previously described.

\section{Results and Discussion}

\subsection{Construction of the initial strains population for genome shuffling.}

The first population of the adapted mutant library was achieved by slowly increasing the concentration of Diazinon from 1000 to $3300 \mathrm{mg} / \mathrm{L}$ over $72 \mathrm{~h}$. The mutant strains (IRLM1.G) were able to grow in $3250 \mathrm{mg} / \mathrm{L}$ of Diazinon, while wild type strain was tolerated for growing in $2900 \mathrm{mg} / \mathrm{L}$. The results are shown in Table 1.

Table 1. First adapted mutant library.

\begin{tabular}{|c|c|c|c|c|}
\hline \multirow{2}{*}{$\begin{array}{l}\text { Concentration of } \\
\text { diazinon }(\mathrm{mg} / \mathrm{L})\end{array}$} & \multirow{2}{*}{ Sample } & \multicolumn{3}{|c|}{ Time } \\
\hline & & $24 \mathrm{~h}$ & $48 \mathrm{~h}$ & $72 \mathrm{~h}$ \\
\hline \multirow{2}{*}{$1000-2600$} & IRLM1.G & + & + & + \\
\hline & IRLM1 & + & + & + \\
\hline \multirow{2}{*}{2700} & IRLM1.G & + & + & + \\
\hline & IRLM1 & - & + & + \\
\hline \multirow{2}{*}{2800} & IRLM1.G & + & + & + \\
\hline & IRLM1 & - & - & + \\
\hline \multirow{2}{*}{2900} & IRLM1.G & + & + & + \\
\hline & IRLM1 & - & + & + \\
\hline \multirow{2}{*}{2950} & IRLM1.G & + & + & + \\
\hline & IRLM1 & - & - & - \\
\hline \multirow{2}{*}{3000} & IRLM1.G & + & + & + \\
\hline & IRLM1 & - & - & - \\
\hline \multirow{2}{*}{3050} & IRLM1.G & + & + & + \\
\hline & IRLM1 & - & - & - \\
\hline \multirow{2}{*}{3100} & IRLM1.G & + & + & + \\
\hline & IRLM1 & - & - & - \\
\hline \multirow{2}{*}{3150} & IRLM1.G & + & + & + \\
\hline & IRLM1 & - & - & - \\
\hline \multirow{2}{*}{3200} & IRLM1.G & + & + & + \\
\hline & IRLM1 & - & - & - \\
\hline \multirow{2}{*}{3250} & IRLM1.G & - & + & + \\
\hline & IRLM1 & - & - & - \\
\hline \multirow{2}{*}{3300} & IRLM1.G & - & - & - \\
\hline & IRLM1 & - & - & - \\
\hline
\end{tabular}

The second population of mutant strains (IRLM1.D) was achieved by treatment with DES $(0.5 \%$ to $3 \% \mathrm{v} / \mathrm{w})$. The number of colonies on the MSM agar containing Diazinon was decreased from $0.5 \%$ to $3 \%$ of DES treatment. The green pigment that is the characteristic of Pseudomonas was not generated at a rate of $2 \%$ and $2.5 \%$ of DES. The mutant strains were 
selected based on the magnitude of halo on LB agar with monocrotophos and the rate of diazinon biodegradation. Therefore, eight mutant strains were considered as the proper choice for genome shuffling. Based on Table 2, the IRLM1.D4 and IRLM1.D8 strains demonstrate satisfying results than other strains. Thus, the IRLM1.D8 strain was considered as one of the parent strains suitable for genome shuffling. Figures 1 and 2 show the diazinon biodegradation at 2000 and $3000 \mathrm{mg} / \mathrm{L}$, respectively. And also, the comparison of whole-cell activity is shown in Figure 3.

Table 2. The second population of mutant strains.

\begin{tabular}{l|c|c} 
Strain name & OD at $\mathbf{2 4 6} \mathbf{~ n m}(\mathbf{2 0 0 0} \mathbf{~ m g} / \mathbf{L})$ & OD at $\mathbf{2 4 6} \mathbf{~ n m}(\mathbf{3 0 0 0} \mathbf{~ m g} / \mathbf{L})$ \\
\hline $\mathrm{C}$ & 0.306 & 1.679 \\
\hline IRLM1 & 0.257 & 1.656 \\
\hline IRLM1.D1 & 0.141 & 1.595 \\
\hline IRLM1.D2 & 0.121 & 1.655 \\
\hline IRLM1.D3 & 0.117 & 1.499 \\
\hline IRLM1.D4 & 0.069 & 1.432 \\
\hline IRLM1.D5 & 0.146 & 1.497 \\
\hline IRLM1.D6 & 0.12 & 1.486 \\
\hline IRLM1.D7 & 0.112 & 1.475 \\
\hline IRLM1.D8 & 0.061 & 1.313
\end{tabular}

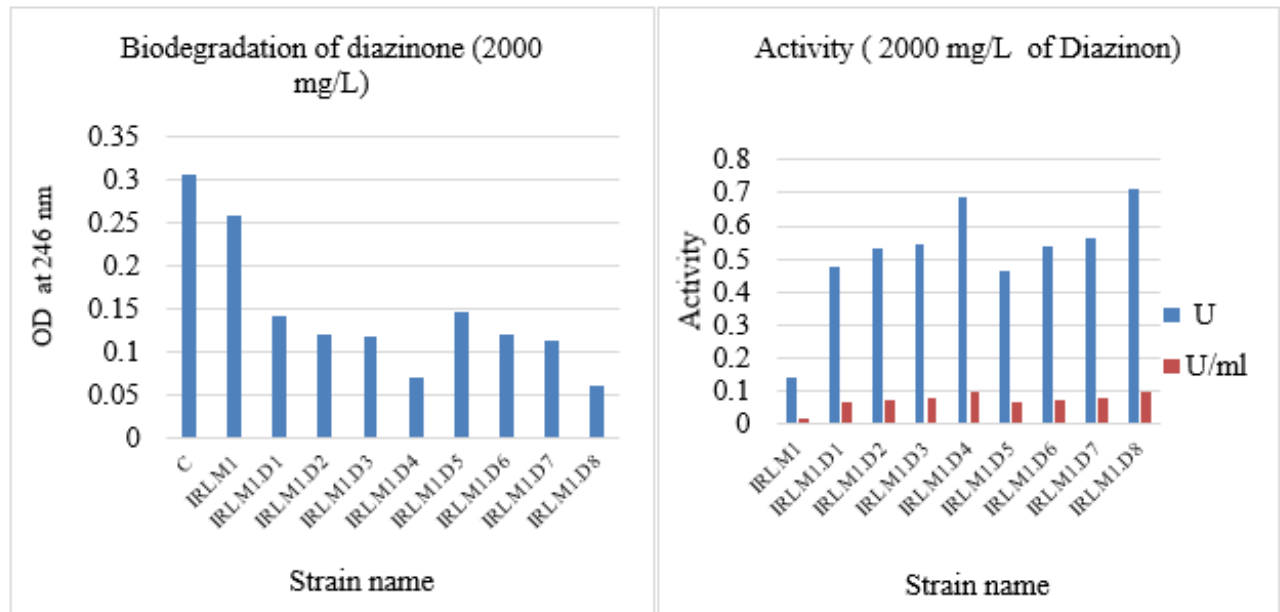

Figure 1. Evaluation of diazinon biodegradation (2000 mg/L diazinon) by improved strains with DES mutagenesis process (A) and calculation of whole-cell activity (B). C: non-inoculated control; IRLM1: wild type strain; IRLM.Ds: starting strains.

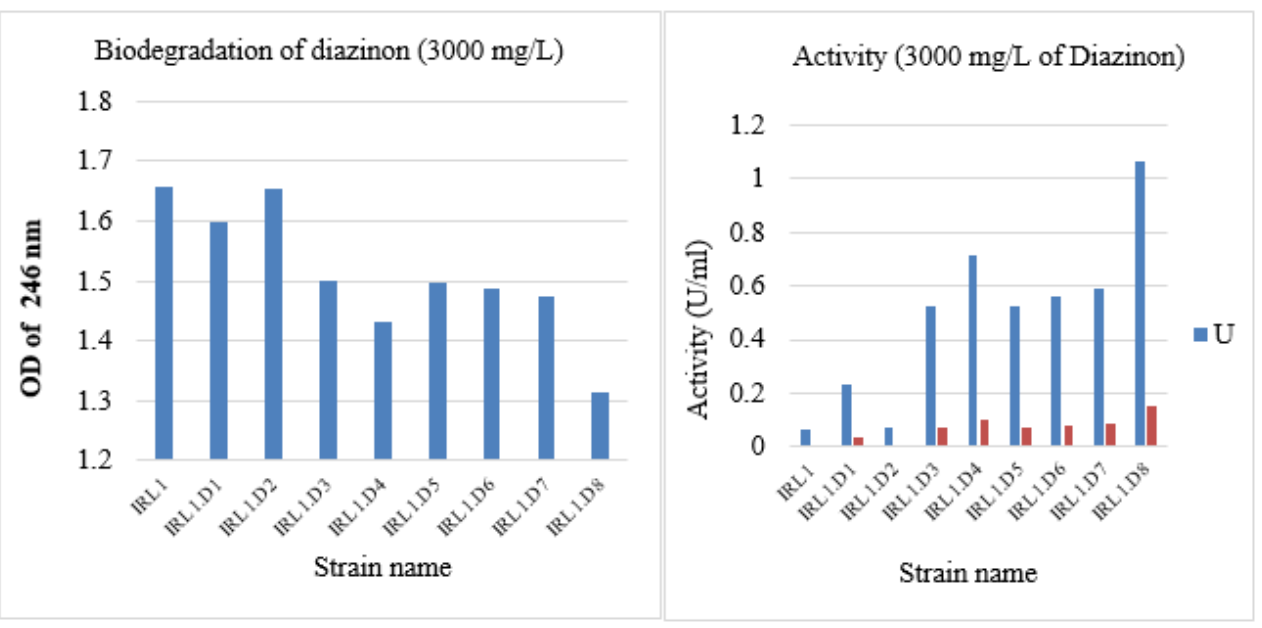

Figure 2. Evaluation of diazinon biodegradation (3000 mg/L of Diazinon) by improved strains with DES mutagenesis process (A) and calculation of whole-cell activity (B). C: non-inoculated control; IRLM1: wild type strain; IRLM.Ds: starting strain. 
Activity (2000 and $3000 \mathrm{mg} / \mathrm{L}$ of Diazinon)

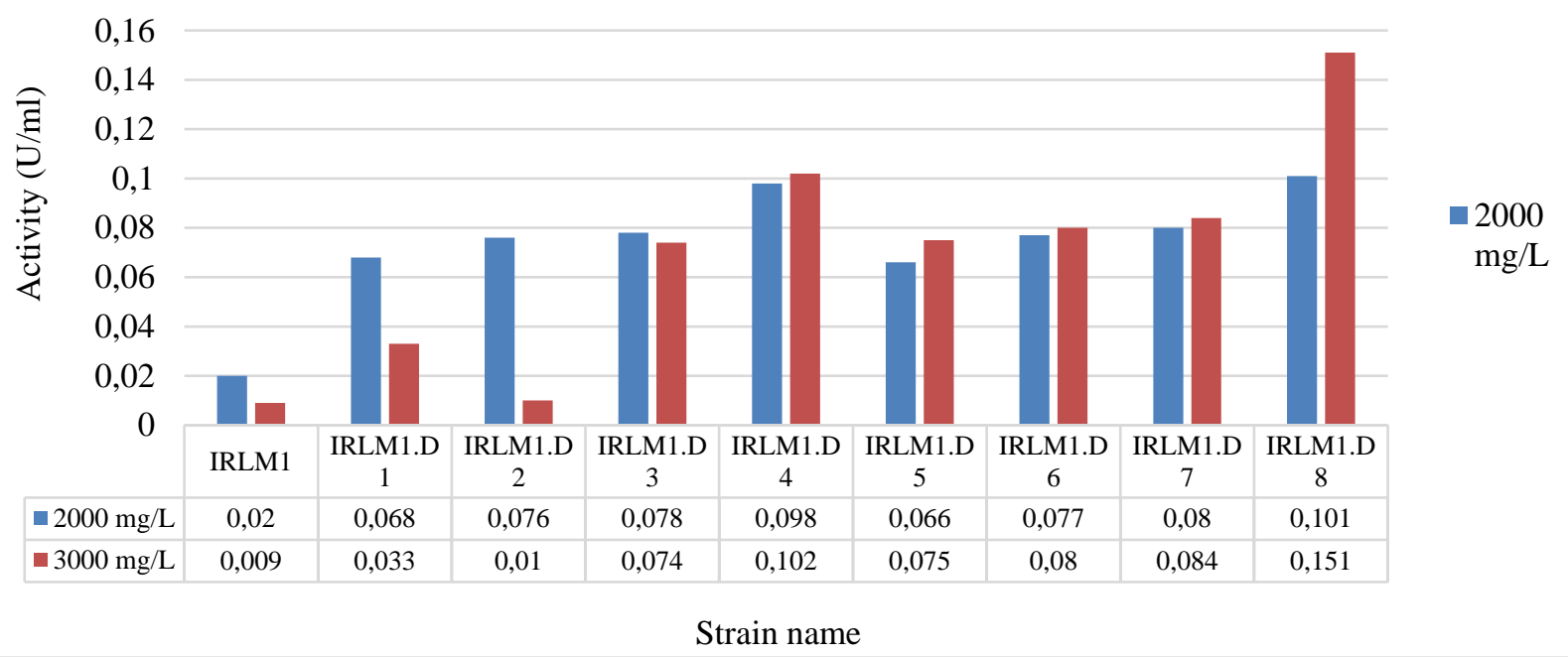

Figure 3. Comparison of whole-cell activity by improved strains with DES in 2000 and $3000 \mathrm{mg} / \mathrm{L}$ of Diazinon.

\subsection{Genome shuffling and screening.}

The created protoplasts were observed by a light microscope after the breakdown of the cell wall with lysozyme (Figure 4). The shuffled strains were selected based on the magnitude of halo on LB agar with monocrotophos. The 12 shuffled strains were selected for analytical methods.

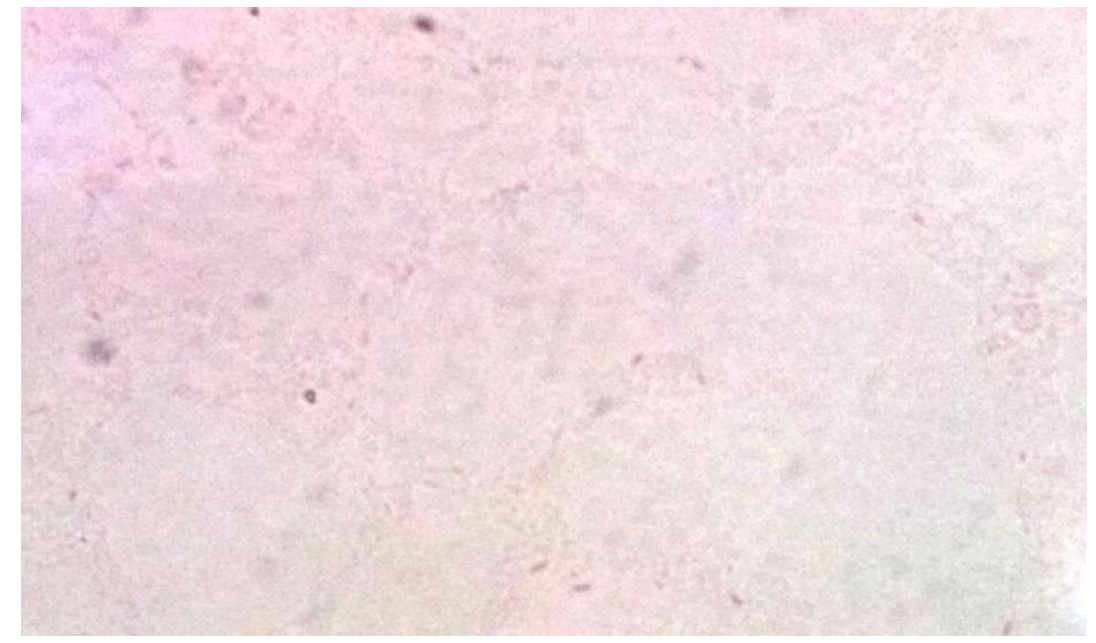

Figure 4. The prepared protoplasts.

\subsection{Bacterial growth and biodegradation of Diazinon in MSM.}

The biodegradation of Diazinon in MSM with Diazinon monitored by optical density $\left(\mathrm{OD}_{246}\right)$ and growth ability of shuffled strains was evaluated by its cultivation in MSM agar with Diazinon. The results showed significant differences $(\mathrm{p}<0.05)$ in the biodegradation rate of individual shuffled strains than parent strains (IRLM1.G and IRLM1.D) and control strains in MSM with Diazinon (Table 3). The results of growth on the MSM agar with Diazinon (3000, 4000 and $5000 \mathrm{mg} / \mathrm{L}$ ) showed that only one of the shuffled strains (IRLM1.F3) was able to grow on $3000 \mathrm{mg} / \mathrm{L}$ diazinon, but only one of them was able to grow on 4000 and $5000 \mathrm{mg} / \mathrm{L}$ of Diazinon. In contrast, the native strain (IRLM1) showed few changes in $\mathrm{OD}_{246}$ than the noninoculated sample. Evaluation of diazinon biodegradation of shuffled strains is shown in Figure 
5. And also, Figure 6 shows the activity of the whole-cell of shuffled strains. The growth of shuffled strains on MSM agar supplemented with Diazinon is presented in Table 4.

Table 3. Shuffled strains.

\begin{tabular}{l|l} 
Strain name & OD $\left._{\mathbf{2 4 6}} \mathbf{~} \mathbf{( 3 0 0 0} \mathbf{~} \mathbf{g} / \mathbf{L}\right)$ \\
\hline C & 1.679 \\
\hline IRLM1 & 1.635 \\
\hline IRLM1.G & 1.112 \\
\hline IRLM1.D & 1.313 \\
\hline IRLM1.F1 & 0.447 \\
\hline IRLM1.F2 & 0.369 \\
\hline IRLM1.F3 & 0.414 \\
\hline IRLM1.F4 & 0.446 \\
\hline IRLM1.F5 & 0.487 \\
\hline IRLM1.F6 & 0.552 \\
\hline IRLM1.F7 & 0.49 \\
\hline IRLM1.F8 & 0.654 \\
\hline IRLM1.F9 & 0.685 \\
\hline IRLM1.F10 & 0.741 \\
\hline IRLM1.F11 & 0.634 \\
\hline IRLM1.F12 & 0.525
\end{tabular}

Biodegradation of diazinon ( $3000 \mathrm{mg} / \mathrm{L}$ )

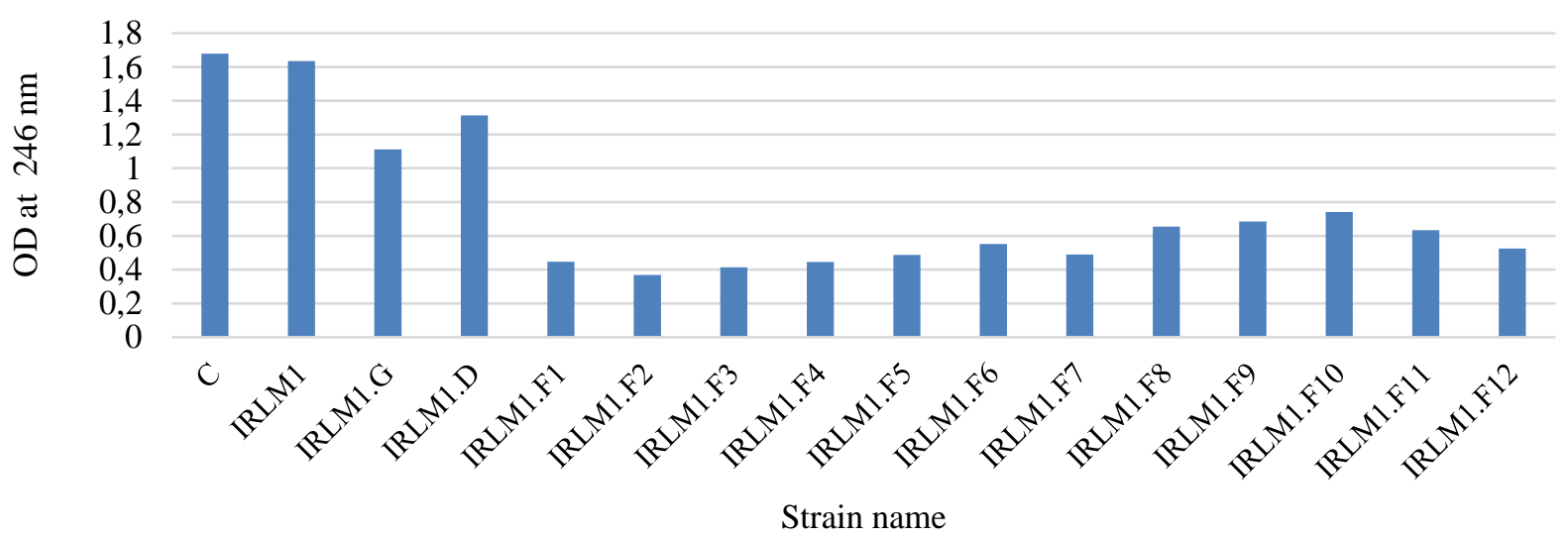

Figure 5. Evaluation of diazinon biodegradation (3000 mg/L of Diazinon) by shuffled strains.

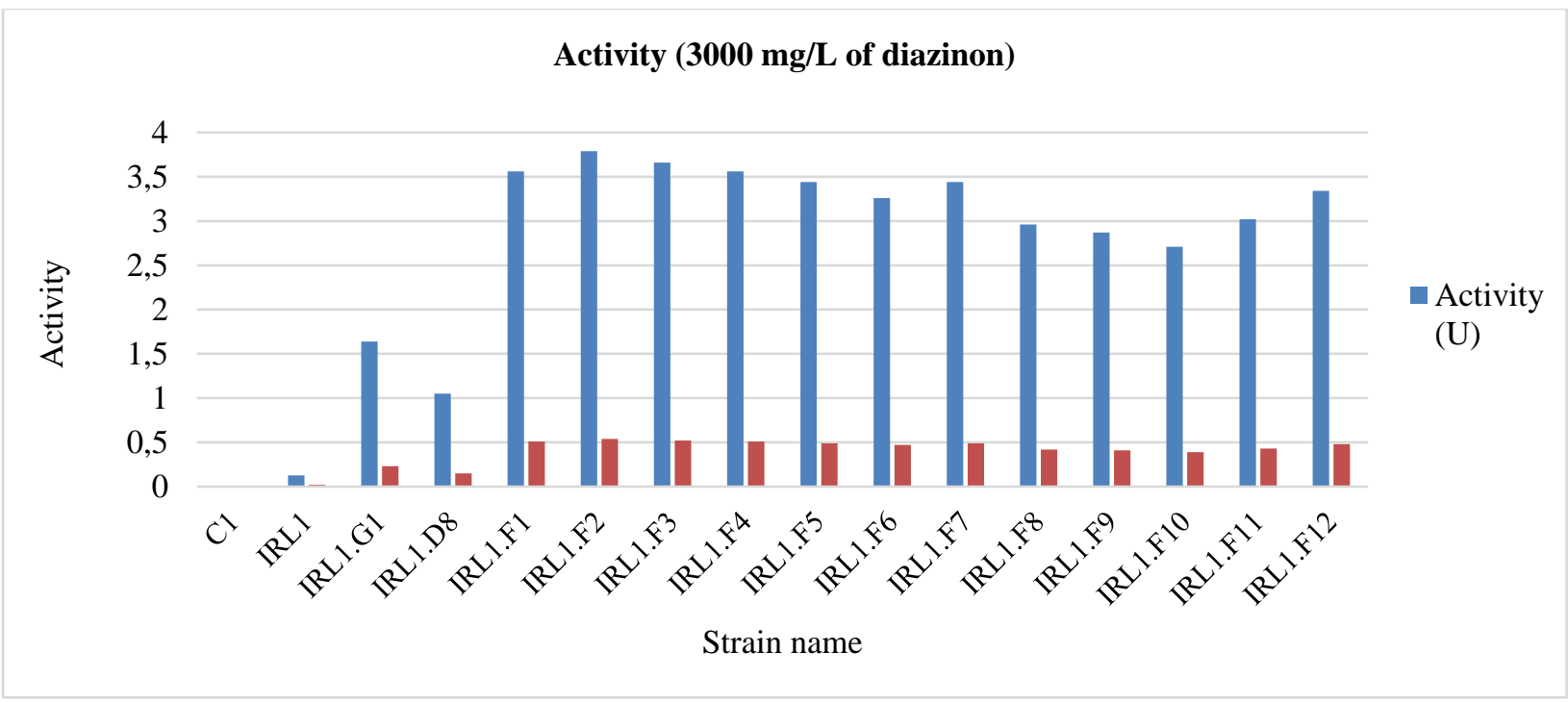

Figure 6. Evaluation of whole-cell activity by shuffled strains in $3000 \mathrm{mg} / \mathrm{L}$ of Diazinon. 
Table 4. Growth of shuffled strains on MSM agar supplemented with Diazinon (in different concentrations).

\begin{tabular}{l|c|c|c|c} 
Sample & $\mathrm{Up}$ to $2500 \mathrm{mg} / \mathrm{L}$ & $3000 \mathrm{mg} / \mathrm{L}$ & $4000 \mathrm{mg} / \mathrm{L}$ & - \\
\hline IRLM1.G & + & + & - & - \\
\hline IRLM1.D & + & - & - & - \\
\hline IRLM1 & + & - & - & - \\
\hline IRLM1.F1 & + & + & + & + \\
\hline IRLM1.F2 & + & + & - & - \\
\hline IRLM1.F3 & + & + & - & - \\
\hline IRLM1.F4 & + & + & - & - \\
\hline IRLM1.F5 & + & + & - & - \\
\hline IRLM1.F6 & + & + & - & - \\
\hline IRLM1.F7 & + & + & - & - \\
\hline IRLM1.F8 & + & + & - & - \\
\hline IRLM1.F9 & + & + & - & - \\
\hline IRLM1.F10 & + & + & - & -
\end{tabular}

Bioremediation of Op compounds from soil and surface water is an essential task. The Flavobacterium sp. ATCC 27551, the first bacterium to degrade Ops, was identified and isolated from the soil of the Philippine. So far, other bacteria have also been found that can use Op compounds as their sole source of carbon, nitrogen, or phosphorus. In various studies, strains of Op compounds have been introduced to clean up the environment. To remove Ops from industrial wastewater, Op degrading bacteria should be able to grow in high Op concentration, therefore, degrade these compounds. The wild type strain in the present study was isolated from soil and effluent storage pools of factories. While in the other study, the Op degrading bacteria had been isolated from the soil of fields. This is a strong point in this research due to our wild type strain, which can grow in higher concentrations of Diazinon (up to $2900 \mathrm{mg} / \mathrm{L}$ ). Additionally, the activity of this wild type strain was improved by the genome shuffling method. Since this study was aiming to improve the bacteria activity and confer the ability to grow in higher Op concentration, Op adaptation and DES mutagenesis was applied. In comparison, in other studied Patnaik et al. (2002) [31] to improve the $\mathrm{pH}$ tolerance and acid production in bacteria, $\mathrm{pH}$ adaptation, and nitrosoguanidine (NTG) mutagenesis was used.

Some changes, such as the increase the tolerance to Ops and the ability to grow in the high concentration of Ops, require tremendous changes in the genome, which are not predictable. After Op adaptation, the IRLM1.G strain was able to tolerate and grow in 3250 $\mathrm{mg} / \mathrm{L}$ of Diazinon. It can be concluded that a gradual increase in diazinon concentration may cause mutation, which leads to adaptation with the new condition. On the other hand, in many studies, DES mutagenesis has been used for the preparation of starting strains. Also, we observed that DES mutagenesis was efficient in obtaining the IRLM1.D8 strain as the improved starting strain. So that the whole-cell activity by the IRLM1D8 was up to 5 and 16.7 fold higher than the wild type strain in 2000 and $3000 \mathrm{mg} / \mathrm{L}$ of Diazinon, respectively. Many mutated strains with DES (IRLM1.F3, 4, 5, 6, and 7) showed an equal increase in biodegradation in 2000 and $3000 \mathrm{mg} / \mathrm{L}$ of Diazinon. Thus, the induced mutations in the genes involved in the decomposition of organophosphate compounds did not disrupt the degrading activity even at a high concentration of Diazinon.

After one round of genome shuffling and screening, all the strains showed remarkable whole-cell activity in $3000 \mathrm{mg} / \mathrm{L}$ diazinon so that the whole-cell activity by IRLM1.F2 and IRLM.F3 was up to 0.52 and $0.54 \mathrm{U} / \mathrm{ml}$, respectively. This activity was 60 and 57.7 fold higher than the wild type strain and 3.5 and 3.4 fold higher than the starting strain. In the study by Wang Ch et al. (2013) [32] after 6 rounds of genome shuffling, 4.2 fold improvement for 
Penicillium citrinum and in the study by Patnaik R et al. (2002) [31] after 5 rounds of genome shuffling 3 fold improvement for Lactobacillus was reported. Zhang Y. F. et al. (2014) [33] also obtained 2.4 fold improvement in Lactococcus lactis after 4 rounds. One of the profound differences between the present study and other studies is the number of genome shuffling rounds, which was performed in just one round compared to several rounds of genome shuffling in other studies. However, the choice of method plays an important role in the final result. In some methods, the outcome shows no difference between the wild type strain and the shuffled strain, and therefore, the enzyme activity remains the same or increases briefly.

So far, the other methods such as DNA shuffling and error-prone PCR [34] have been used to produce recombinant strains by several researchers, but the use of microorganisms in bioremediation has its advantages such as stability, adaptation to the environment, costeffective and easy production. Several bacteria with almost identical opd sequences have been identified from around the world. The opd gene exists in the genome of several bacteria. The gene that is responsible for the breakdown of Diazinon and other Ops is opd, which also can be found in Pseudomonas Strain.

Although all fusants showed improved activity compared to the wild type, only IRLM1.F3 was able to grow in a media containing more than $3000 \mathrm{mg} / \mathrm{L}$ of diazinon concentration. Other strains, despite their increased activity, were not able to grow in higher concentrations of Diazinon. Nevertheless, the occurrence of both increased activity and the ability to grow in high concentrations of Diazinon is less likely. Thus, we successfully obtained the IRLM1.F3 strain with increased activity (57.7 fold higher than wild type strain) and the ability to grow in high concentrations (up to $5000 \mathrm{mg} / \mathrm{L}$ ) of Diazinon after one round of genome shuffling.

\section{Conclusions}

The genome shuffling could easily and rapidly improve the characteristics of microorganisms to be used in commercial applications. Based on our results, the IRLM1.F2 strain was considered as the candidate strain for industrial production in bioremediation purposes, especially in wastewater treatment. It can also be used for the characterization of the mutations responsible for improved activity and tolerance.

\section{Funding}

This research received no external funding.

\section{Acknowledgments}

The authors thank the Research Council of Baqiyatallah University of Medical Sciences for their kind help.

\section{Conflicts of Interest}

The authors declare no conflict of interest.

\section{References}

1. Narang, U.; Narang, P.; Gupta, O. Organophosphorus poisoning: A social calamity. J Mahatma Gandhi Inst Med Sci 2015, 20, https://doi.org/10.4103/0971-9903.151736. 
2. Liu, W.; Quan, J.; Hu, Z. Detection of Organophosphorus Pesticides in Wheat by Ionic Liquid-Based Dispersive Liquid-Liquid Microextraction Combined with HPLC. J Anal Methods Chem 2018, 2018, https://doi.org/10.1155/2018/8916393.

3. Luo, R.; Feng, Z.; Shen, G.; Xiu, Y.; Zhou, Y.; Niu, X.; Wang, H. Acetylcholinesterase Biosensor Based On Mesoporous Hollow Carbon Spheres/Core-Shell Magnetic Nanoparticles-Modified Electrode for the Detection of Organophosphorus Pesticides. Sensors (Basel) 2018, 18, https://doi.org/10.3390/s18124429.

4. Wang, T.F.; Lo, H.F.; Chi, M.C.; Lai, K.L.; Lin, M.G.; Lin, L.L. Affinity Immobilization of a Bacterial Prolidase onto Metal-Ion-Chelated Magnetic Nanoparticles for the Hydrolysis of Organophosphorus Compounds. Int J Mol Sci 2019, 20, https://doi.org/10.3390/ijms20153625.

5. Gianessi, L.P. The increasing importance of herbicides in worldwide crop production. Pest Manag Sci 2013, 69, 1099-105, https://doi.org/10.1002/ps.3598.

6. Cardozo, M.; de Almeida, J.S.F.D.; Cavalcante, S.F.d.A.; Salgado, J.R.S.; Gonçalves, A.S.; França, T.C.C.; Kuca, K.; Bizzo, H.R. Biodegradation of Organophosphorus Compounds Predicted by Enzymatic Process Using Molecular Modelling and Observed in Soil Samples Through Analytical Techniques and Microbiological Analysis: A Comparison. Molecules 25, https://doi.org/10.3390/molecules25010058.

7. Huang, P.; Li, B.; Feng, S.; Guo, Y.; Zhao, G.; Wang, D.; Liu, Q. Xuebijing injection for acute organophosphorus pesticide poisoning: a systematic review and meta-analysis. Ann Transl Med 2019, 7, 112, https://doi.org/10.21037/atm.2018.12.22.

8. Li, R.; Yang, J.; Xiao, Y.; Long, L. In vivo immobilization of an organophosphorus hydrolyzing enzyme on bacterial polyhydroxyalkanoate nano-granules. Microb Cell Fact 2019, 18, 166, https://doi.org/10.1186/s12934-019-1201-2.

9. Atarod, M.; Safari, J.; Tebyanian, H. Ultrasound irradiation and green synthesized CuO-NiO-ZnO mixed metal oxide: An efficient sono/nano-catalytic system toward a regioselective synthesis of 1-aryl-5-amino1H-tetrazoles. Synth. Commun 2020, 1-14, https://doi.org/10.1080/00397911.2020.1761396.

10. Thakur, M.; Medintz, I.L.; Walper, S.A. Enzymatic Bioremediation of Organophosphate CompoundsProgress and Remaining Challenges. Front Bioeng Biotechnol 2019, 7, https://doi.org/10.3389/fbioe.2019.00289.

11. Rücker, C.; Mahmoud, W.M.M.; Schwartz, D.; Kümmerer, K. Biodegradation tests of mercaptocarboxylic acids, their esters, related divalent sulfur compounds and mercaptans. Environ. Sci. Pollut. Res 2018, 25 , 18393-18411, https://doi.org/10.1007/s11356-018-1812-X.

12. Grösbacher, M.; Eckert, D.; Cirpka, O.A.; Griebler, C. Contaminant concentration versus flow velocity: drivers of biodegradation and microbial growth in groundwater model systems. Biodegradation 2018, 29, 211-232, https://doi.org/10.1007/s10532-018-9824-2.

13. Amini, B.; Otadi, M.; Partovinia, A. Statistical modeling and optimization of Toluidine Red biodegradation in a synthetic wastewater using Halomonas strain Gb. J Environ Health Sci 2019, 17, 319-330, https://doi.org/10.1007/s40201-019-00350-5.

14. Ojaghi, A.; Tonkaboni, S.Z.S.; Shariati, P.; Ardejani, F.D. Novel cyanide electro-biodegradation using Bacillus pumilus ATCC 7061 in aqueous solution. J Environ Health Sci 2018, 16, 99-108, https://doi.org/10.1007/s40201-018-0289-3.

15. Satish, G.P.; Ashokrao, D.M.; Arun, S.K. Microbial degradation of pesticide: A review. Afr. J. Microbiol. Res 2017, 11, 992-1012, https://doi.org/10.5897/ajmr2016.8402.

16. Mulbry, W.W.; Karns, J.S. Parathion hydrolase specified by the Flavobacterium opd gene: relationship between the gene and protein. J Bacteriol 1989, 171, 6740-6, https://doi.org/10.1128/jb.171.12.67406746.1989.

17. Serdar, C.M.; Murdock, D.C.; Rohde, M.F. Parathion Hydrolase Gene from Pseudomonas diminuta MG: Subcloning, Complete Nucleotide Sequence and Expression of the Mature Portion of the Enzyme in Escherichia coli. Nat. Biotechnol 1989, 7, 1151-1155, https://doi.org/10.1038/nbt1189-1151.

18. Arora, P.K.; Sasikala, C.; Ramana, C.V. Degradation of chlorinated nitroaromatic compounds. Appl Microbiol Biotechnol 2012, 93, 2265-77, https://doi.org/10.1007/s00253-012-3927-1.

19. Khodi, S.; Latifi, A.M.; Saadati, M.; Mirzaei, M.; Aghamollaei, H. Surface display of organophosphorus hydrolase on E. coli using N-terminal domain of ice nucleation protein InaV. J Microbiol Biotechnol 2012, 22, 234-8, https://doi.org/10.4014/jmb.1104.04011.

20. Latifi, A.M.; Khajeh, K.; Farnoosh, G.; Hassanpour, K.; Khodi, S. The Cytoplasmic and Periplasmic Expression Levels and Folding of Organophosphorus Hydrolase Enzyme in Escherichia coli. Jundishapur J Microbiol 2015, 8, https://doi.org/10.5812/jjm.17790.

21. Khomarlou, N.; Aberoomand-Azar, P.; Lashgari, A.P.; Tebyanian, H.; Hakakian, A.; Ranjbar, R.; Ayatollahi, S.A. Essential oil composition and in vitro antibacterial activity of Chenopodium album subsp. striatum. Acta Biologica Hungarica 2018, 69, 144-155, https://doi.org/10.1556/018.69.2018.2.4.

22. Mirzaei, M.; Khorshahi, H.; Tebyanian, H.; Seid Moradi, R.; Rastegar Shariat Panahi, M.; Sariri, R.; Latifi, A. The Effect of Deep Eutectic Solvents as Co-solvent on Organophosphorus Hydrolase Targeting Engineering Enzyme-catalyzed. Biointerface Res. Appl. Chem 2020, 10, 6488-6497, https://doi.org/10.33263/BRIAC105.64886497. 
23. Leja, K.; Myszka, K.; Czaczyk, K. Genome shuffling: a method to improve biotechnological processes. BioTechnologia 2011, 92, https://doi.org/10.5114/bta.2011.46551.

24. Heidari, M.F.; Arab, S.S.; Noroozi-Aghideh, A.; Tebyanian, H.; Latifi, A.M. Evaluation of the substitutions in 212, 342 and 215 amino acid positions in binding site of organophosphorus acid anhydrolase using the molecular docking and laboratory analysis. Bratisl Lek Listy 2019, 120, 139-143, https://doi.org/10.4149/bll_2019_022.

25. Aberoomand Azar, P.; Moradi, S.; Piramoon, S.; Mashinchian Moradi, A. Photocatalytic Degradation of Diazinon From Marine Source Using TiO2/SiO2 Thin Layer Coated on Glass. IJMASE 2011, 1, 23-28,

26. Cycoń, M.; Wójcik, M.; Piotrowska-Seget, Z. Biodegradation of the organophosphorus insecticide diazinon by Serratia sp. and Pseudomonas sp. and their use in bioremediation of contaminated soil. Chemosphere 2009, 76, 494-501, https://doi.org/10.1016/j.chemosphere.2009.03.023.

27. Zolfaghar, M.; Amoozegar, M.A.; Khajeh, K.; Babavalian, H.; Tebyanian, H. Isolation and screening of extracellular anticancer enzymes from halophilic and halotolerant bacteria from different saline environments in Iran. Mol. Biol. Rep 2019, 46, 3275-3286, https://doi.org/10.1007/s11033-019-04787-7.

28. Rezaeeyan, Z.; Safarpour, A.; Amoozegar, M.A.; Babavalian, H.; Tebyanian, H.; Shakeri, F. High carotenoid production by a halotolerant bacterium, Kocuria sp. strain QWT-12 and anticancer activity of its carotenoid. EXCLI J 2017, 16, 840-851, https://doi.org/10.17179/excli2017-218.

29. Tebyanian, H.; Mirhosseiny, S.H.; Kheirkhah, B.; Hassanshahian, M. Isolation and Identification of Mycoplasma synoviae From Suspected Ostriches by Polymerase Chain Reaction, in Kerman Province, Iran. Jundishapur J. Microbiol 2014, 7, https://doi.org/10.5812/jjm.19262.

30. Morelli, L.; Cocconcelli, P.S.; Bottazzi, V.; Damiani, G.; Ferretti, L.; Sgaramella, V. Lactobacillus protoplast transformation. Plasmid 1987, 17, 73-5, https://doi.org/10.1016/0147-619X(87)90013-8.

31. Patnaik, R.; Louie, S.; Gavrilovic, V.; Perry, K.; Stemmer, W.P.; Ryan, C.M.; del Cardayre, S. Genome shuffling of Lactobacillus for improved acid tolerance. Nat Biotechnol 2002, 20, 707-12, https://doi.org/10.1038/nbt0702-707.

32. Wang, C.; Wu, G.; Li, Y.; Huang, Y.; Zhang, F.; Liang, X. Genome shuffling of Penicillium citrinum for enhanced production of nuclease P1. Appl Biochem Biotechnol 2013, 170, 1533-45, https://doi.org/10.1007/s12010-013-0297-9.

33. Zhang, Y.F.; Liu, S.Y.; Du, Y.H.; Feng, W.J.; Liu, J.H.; Qiao, J.J. Genome shuffling of Lactococcus lactis subspecies lactis YF11 for improving nisin Z production and comparative analysis. J Dairy Sci 2014, 97, 2528-41, https://doi.org/10.3168/jds.2013-7238.

34. Rezaie, E.; Latifi, A.M.; Mirzaei, M. Activity improvement of organophosphorus hydrolase enzyme by error prone PCR method. Journal of Applied Biotechnology Reports 2018, 5, 100-4. 